\title{
DNA Mismatch Repair and DNA Methylation in Adult Brain Neurons
}

\author{
P. J. Brooks, Cheryl Marietta, and David Goldman
}

Section on Molecular Neurobiology, Laboratory of Neurogenetics, National Institute on Alcohol Abuse and Alcoholism, Rockville, Maryland 20852

DNA repair is essential for maintaining the integrity of the nucleotide sequence of cellular DNA over time. Although much information has accumulated recently on the mechanisms of DNA repair in cultured cells, little is known about the DNA repair capabilities of cells in the adult brain. In the present study, we have investigated the capacity of nuclear extracts from adult rodent brain neurons to carry out DNA mismatch repair. We focused on the repair of $G \cdot T$ and $G \cdot U$ mismatches, which are caused by deamination of 5-methyl cytosine to thymine, or cytosine to uracil, respectively, because these are the only types of mismatches that can arise in nondividing cells. We found that nuclear extracts from adult brain neurons can correct $G \cdot T$ and $G \cdot U$ mismatches, restoring them to $G: C$ base pairs. Several other types of DNA mismatches could not be

The ability to analyze complex DNA repair processes in nuclear extracts from the adult brain will be useful for analyzing changes in DNA repair capacity under different experimental and pathological conditions. DNA repair is essential for maintaining the inherited nucleotide sequence of genomic DNA over time. Repair of nonreplicating DNA would be expected to be particularly important in neurons, because neurons are among the longestlived cells in the body. There has been great progress recently in understanding the molecular mechanism of several types of DNA repair processes in cultured cells (Cleaver, 1994; Hanawalt, 1994; Modrich, 1994; Sancar, 1994). However, although several DNA repair enzymes have been identificd in the brain (Waser et al., 1979; Kuenzle, 1985; Walker and Bachelard, 1988; Mazzarello et al., 1992; Ran, 1993; Weng and Sirover, 1993), little is known about the ability of brain cells to carry out specific types of DNA repair reactions. The importance of this information is underscored by the findings of neurological impairments in Xeroderma pigmentosum and Cockayne's syndrome, two genetic conditions involving deficiencies in DNA repair (Cleaver, 1968; Troclstra et al., 1993). There is also evidence for alterations in DNA repair capability in other neurological conditions including Alzheimer's disease (Robbins et al., 1985), Huntington's disease (Scuderio et al., 1981), and amyotrophic lateral sclerosis (Tandan et al., 1987). Finally, there is interesting data suggesting that DNA sequences in the vasopressin gene are unstable during aging in adult postmitotic neurons (Evans et al., 1994). Thus, there is clearly a need for systems in which different DNA repair processes can be studied in brain tissuc.

\footnotetext{
Received July 12, 1995; revised Oct. 25, 1995; accepted Oct. 31. 1995

We thank Dr. Josef Jiricny for providing antisera used in preliminary studies.

Correspondence should be addressed to Dr. P. Brooks, Section on Molecular Neurobiology. Laboratory of Neurogenetics, NIAAA. 12501 Washington Avenue, Rockville, MD 20852.

Copyright 1996 Society for Neuroscience $0270-6474 / 96 / 160939-\bullet \$ 05.00 / 0$
}

processed. These data provide the first direct demonstration that neurons in the adult mammalian brain have the capability to carry out DNA mismatch repair. We also we report that adult brain contains high levels of DNA methyltransferase (MTase) activity. We propose that one function of DNA MTase in the adult brain is to remethylate newly incorporated cytosine residues from G.T mismatch repair after deamination of 5-methyl cytosine, thereby maintaining the original pattern of DNA methylation. The high levels of brain DNA MTase suggest further that this enzyme has additional functions in the brain.

Key words: DNA repair; DNA methylation; neurons; mutation; cancer; cell nucleus; 5-methyl cytosine; DNA glycosylase; mismatch repair
In the present study, we examined the capability of the nuclear extracts from neurons in the adult rodent brain to repair naturally occurring DNA mismatches that arise spontaneously becausc of the hydrolytic deamination of cytosine and 5-methyl cytosine (5-MeC) residues. Deamination of 5-MeC generates thymine and, in an analogous manner, deamination of cytosine generates uracil (Bestor and Coxon, 1993; Lindahl, 1993; Wiebauer et al., 1993). Based on the rate of spontaneous deamination in vitro, it has been estimated that $1-205-\mathrm{MeC}$ residues and $-100-500$ cytosine residues deaminate per human cell per day (Lindahl, 1993; Wiebauer et al., 1993; Shen et al., 1994). The spontaneous deamination of $5-\mathrm{MeC}$ to $\mathrm{T}$, in particular, plays an important role in mutagenesis and cancer (Rideout et al., 1990; Lindahl, 1993).

Deamination of $5-\mathrm{MeC}$ to thymine generates a $\mathrm{G} \cdot \mathrm{T}$ mismatch in genomic DNA, and deamination of cytosine to uracil generates a $\mathrm{G} \cdot \mathrm{U}$ mismatch. Mammalian cells in culture have been shown to possess $G \cdot T$ and $G \cdot U$ mismatch repair activities that convert these types of mismatches back to $\mathrm{G}: \mathrm{C}$ base pairs (Brown and Jiricny, 1987; Dianov et al., 1992). In adult brain neurons that are not undergoing DNA replication, $G \cdot T$ and $G \cdot U$ mismatches caused by spontaneous deamination are the only two types of DNA mismatches that are likely to occur. Therefore, we examined the capacity of nuclear extracts from adult brain neurons to repair the $\mathrm{G} \cdot \mathrm{T}$ and $\mathrm{G} \cdot \mathrm{U}$ mismatches in vitro. We found that neuronal nuclear extracts could repair both types of mismatches. In addition, we demonstrate that brain neuronal nuclei contain DNA methyltransferase (MTase). We propose that one function of DNA MTase in the brain is to remethylate newly incorporated cytosines after $\mathrm{G} \cdot \mathrm{T}$ mismatch repair, thereby maintaining the inherited pattern of DNA methylation.

\section{MATERIALS AND METHODS}

Oligonucleotides. 34-Mer oligodeoxyribonucleotides were synthesized on an Applied Biosystems 380A DNA synthesizer (Foster City, CA). Phos- 
phoramidites were from Applied Biosystems, except for the dU phosphoramidite, which was purchased from Glen Research (Sterling, VA). After synthesis, oligos were deprotected in $\mathrm{NH}_{4} \mathrm{OH}$ at $50^{\circ} \mathrm{C}$ overnight. Oligos were laheled at the $5^{\prime}$ end with $\left[\gamma_{-}{ }^{32} \mathrm{P}\right] \mathrm{ATP}$ and then annealed by heating in tetracycline containing $0.1 \mathrm{M} \mathrm{NaCl}$. Annealed oligos were purified on nondenaturing polyacrylamide gels, cut out, and eluted overnight. Labeled duplexes were recovered by ethanol precipitation and diluted in $0.1 \mathrm{M} \mathrm{NaCl}$ at $\sim 20 \mathrm{fmol} / \mu \mathrm{l}$.

Preparation of cell extracts. Whole-cell extracts for nicking assays were prepared by a modification of the procedure of Neddermann and Jiricny (1993). Rats were killed by $\mathrm{CO}_{2}$ inhalation, and the whole brain (minus olfactory bulbs) was removed, weighed, then chopped using a razor blade at $4^{\circ} \mathrm{C}$. All subsequent procedures were carried out at in a cold room. Chopped tissues were suspended in 4 vol of buffer $J$ [ $20 \mathrm{mM}$ HEPES, pH $7.9, .1 \mathrm{~mm}$ EDTA, $0.5 \mathrm{~mm}$ spermidine, $0.1 \mathrm{~mm}$ spermine, $2 \mathrm{~mm}$ dithio-threitol (DTT)] containing the following protease inhibitors: 1 mM Pefabloc (Boehringer Mannheim, Indianapolis, IN) $1 \mu \mathrm{g} / \mathrm{ml}$ pepstatin, $1 \mu \mathrm{g} / \mathrm{ml}$ leupeptin, and $10 \mu \mathrm{g} / \mathrm{ml}$ aprotinin. Tissues were dispersed using a wide-bore pipette, then allowed to swell in buffer for 20 min. Tissues then were homogenized using 20 strokes of a glass Dounce homogenizer. Glycerol was added to a find concentration of $20 \%$, followed by the addition of saturated ammonium sulfate $(11 \mu \mathrm{l} / 100 \mu \mathrm{l}$ extract). Homogenates then were rocked slowly for $20 \mathrm{~min}$ in the cold room. Supernatants were prepared by microcentrifugation for $20 \mathrm{~min}$ at $14,000 \mathrm{rpm}$ in an Eppendorf centrifuge. The supernatant was removed and diluted 1:4 with HE buffer ( $25 \mathrm{~mm}$ HEPES, $1 \mathrm{~mm}$ EDTA, $10 \%$ glycerol, $1 \mathrm{~mm}$ DTT, and protease inhibitors as indicated above). A volume of DEAE-Sephacel [25\% (v/v) in HE buffer plus $0.1 \mathrm{M} \mathrm{NaCl}]$ equal to the original supernatant was added and mixed, and the suspensions were rocked for $20 \mathrm{~min}$. The DEAE-Sephacel was removed by centrifugation, and the supernatants were concentrated and desalted by centrifugation in Microcon 30 concentrators (Amicon, Beverly, MA) as directed by the manufacturer. Concentrated extracts were aliquoted, frozen on dry ice, and stored at $-80^{\circ} \mathrm{C}$.

Nuclear extract preparation. For nuclear extract preparation, adult rats (Charles River Laboratories, Wilmington, MA) were killed by $\mathrm{CO}_{2}$ narcosis. Nuclei were isolated as described previously (Thompson, 1987). Cerebella were removed, placed into $0.32 \mathrm{~m}$ sucrose containing $1 \mathrm{~mm}$ $\mathrm{MgCl}_{2}$, and transferred to a cold room. Tissues were removed, weighed, chopped with a razor blade, and then homogenized in $2.0 \mathrm{M}$ sucrose $/ 1 \mathrm{mM}$ $\mathrm{MgCl}_{2}$ containing protease inhibitors as described above. Homogenates were diluted with an equal volume of $2.2 \mathrm{M}$ sucrose $/ 1 \mathrm{~mm} \mathrm{MgCl}$ and then centrifuged at $64,000 \times g$ for $30 \mathrm{~min}$ in a Beckman SW 28 rotor (Beckman Instruments, Fullerton, CA). Supernatants were decanted, and nuclear pellets were resuspended in nuclear storage buffer $(25 \%$ glycerol, $50 \mathrm{~mm}$ Tris, pH 7.6, 5.0 mM Mg-acetate, $1 \mathrm{~mm} \mathrm{DTT}$, and 0.1 mM EDTA) at $\sim 10^{8}$ nuclei $/ \mathrm{ml}$. Aliquots were removed for nuclear counting, and the remaining samples were frozen on dry ice and stored at $-80^{\circ} \mathrm{C}$.

For extraction of nuclei, tubes containing $\sim 10^{8}$ nuclei were thawed and nuclei were collected by brief microfuge centrifugation. Nuclei were dispersed in buffer $\mathbf{J}$ (see above) containing $20 \%$ glycerol. A 1:10 volume of saturated ammonium sulfate was added dropwise, and the tubes were rocked at $4^{\circ} \mathrm{C}$ for $30 \mathrm{~min}$. The extracts then were diluted 1:3 with $\mathrm{HE}$ buffer containing 25\% DEAE-Sephacel and rocked for an additional 20 min. The DEAE-Sephacel and insoluble nuclear material were collected by centrifugation. Supernatants were removed and concentrated on Microcon 30 colunns, as described above, and stored at $-80^{\circ} \mathrm{C}$.

DNA heteroduplex nicking assays. Nicking assays were conducted essentially as described previously (Neddermann and Jiricny, 1993). Nicking buffer contained 25 mm HEPES, pH 7.9, 1 mm EDTA, 1 mm DTT, $10 \mu \mathrm{M}$ $\mathrm{ZnCl}_{2}, 100 \mu \mathrm{g} / \mathrm{ml}$ bovine serum albumin (BSA), and $5 \mu \mathrm{l}$ of tissue extracts (5-10 $\mu \mathrm{g}$ of protein), and 5-20 fmol of ${ }^{32} \mathrm{P}$ end-labeled duplex DNA. Reactions were incubated at $30^{\circ} \mathrm{C}$ overnight $(12-16 \mathrm{hr})$. After the incubations, the DNA was ethanol-precipitated from $2.5 \mathrm{M}$ ammonium acetate, resuspended in formamide loading dye (95\% deionized formamide, $1 \mathrm{mM}$ EDTA, and $0.001 \%$ xylene cyanol and bromophenol blue), heated at $90^{\circ} \mathrm{C}$ for $3 \mathrm{~min}$, and electrophoresed through $18 \%$ polyacrylamide gels containing $8 \mathrm{M}$ urca in Tris borate EDTA. Gels were dricd and exposed to Kodak XAR film (Rochester, NY).

DNA mismatch repair assays. Repair reactions were carried out in the buffer described above supplemented with $0.5 \mathrm{~mm}$ EDTA, $1 \mathrm{mM} \mathrm{MgCl}$, $1 \mathrm{~mm}$ ATP, $40 \mathrm{~mm} \mathrm{KCl}, 20 \mathrm{~mm}$ creatine phosphate, and $100 \mu \mathrm{M}$ of each deoxynucleotide triphosphate. Reactions were incubated at $37^{\circ} \mathrm{C}$ overnight. Reactions were stopped by the addition of $100 \mu \mathrm{g} / \mathrm{ml}$ proteinase $\mathrm{K}$, $20 \mathrm{~mm}$ Tris, $\mathrm{pH} 8.0,25 \mathrm{~mm}$ EDTA, and $1 \%$ SDS, and were incubated at $37^{\circ} \mathrm{C}$ for $30 \mathrm{~min}$. Next they were extracted with buffered phenol, extracted with chloroform, and then ethanol-precipitated with $5 \mu \mathrm{g}$ of tRNA. Samples were resuspended in $50 \mu \mathrm{l}$ of buffer H (Boehringer Mannheim, Indianapolis, IN). A $25 \mu \mathrm{l}$ aliquot was removed, and $2 \mathrm{U}$ of SalI (Boehringer Mannheim) was added and incubated for $90 \mathrm{~min}$ at $37^{\circ} \mathrm{C}$ along with the remaining $25 \mu \mathrm{l}$ that had water added instead of SalI. At the end of the incubation period, the reactions were ethanol-precipitated again and then resuspended in formamide loading dye and fractionated by denaturing gel electrophoresis as described above.

Exiraction of MTase. Tissue extracts for analysis of MTase activity were prepared essentially as described by $\mathrm{Li}$ et al. (1992) with minor modifications. All procedures were performed at $4^{\circ} \mathrm{C}$. Tissues were homogenized in 5 vol of extraction buffer $(20 \mathrm{~mm}$ Tris, $\mathrm{pH} 7.4,0.4 \mathrm{M} \mathrm{NaCl}, 25 \%$ glycerol, $5 \mathrm{~mm}$ EDTA, $1 \mathrm{~mm}$ DTT, $0.1 \%$ Nonidet P-40, $100 \mu \mathrm{g} / \mathrm{ml}$ aprotinin, and $1 \mathrm{~mm}$ AEBSF). After homogenization, one vol of DEAESephacel ( $50 \%$ slurry in $20 \mathrm{~mm}$ Tris, $\mathrm{pH} 7.4$ ) was added, and the mixture was rocked for $10 \mathrm{~min}$. The extracts then were centrifuged at $10,000 \mathrm{rpm}$ in an Eppendorf centrifuge for $10 \mathrm{~min}$ to pellet Sephacel and insoluble material. The clarified supernatant was removed, aliquoted, rapidly frozen on dry ice, and stored at $-80^{\circ} \mathrm{C}$ until use. Cerebellar nuclei (isolated as described above) were extracted using the same procedure.

Measurement of MTase activity. MTase activity was assayed essentially as described previously ( $\mathrm{Li}$ et al., 1992) with minor modifications. Twenty microliters of extract $(20-160 \mu \mathrm{g}$ of tissue protein) were added to $200 \mu \mathrm{l}$ of the reaction mixture, which contained $20 \mathrm{~mm}$ Tris, $\mathrm{pH} \mathrm{7.4,5 \textrm {mm }}$ EDTA, $1 \mathrm{~mm}$ DTT, $25 \%$ glycerol, $200 \mu \mathrm{g} / \mathrm{ml}$ BSA, $5 \mu \mathrm{Ci}\left[{ }^{3} \mathrm{H}\right]$ methyl- $S$ adenosyl-L-methionine $(10-15 \mathrm{Ci} / \mathrm{mmol}$, DuPont NEN, Boston, MA) and $4 \mu \mathrm{g}$ of poly dIdC as the methyl-acceptor DNA. Blank reactions (which lacked poly $\mathrm{dIdC}$ ) were set up in parallel to determine background. Reactions were incubated for $60 \mathrm{~min}$ at $37^{\circ} \mathrm{C}$ and then extracted twice with buffered phenol/chloroform (1:1). The aqueous phase was made 0.1 $\mathrm{M}$ in $\mathrm{NaOH}$ and incubated at $50^{\circ} \mathrm{C}$ for $2 \mathrm{hr}$, and then neutralized with $\mathrm{HCl}$. Aliquots of the mixture were spotted onto DE-81 filters, which then were washed three times in $0.5 \mathrm{M} \mathrm{NaPO}_{4}, \mathrm{pH} 6.8$, and dried. Filters were counted in a scintillation counter $(\sim 50 \%$ efficiency). For each sample, background counts from parallel reactions lacking poly $\mathrm{dIdC}$ were subtracted, and specific counts were normalized to the protein content of the samples. Data are expressed as pmol of $\mathrm{CH}_{3}$ transferred - mig protein $^{-1} \cdot \mathrm{hr}^{-\mathrm{i}}$

Preliminary experiments using extracts from mouse cerebellum showed that the assay was linear with respect to time and protein concentration under these conditions.

Other. Protein content of the extracts was determined using the BioRad protein assay kit (Hercules, CA).

\section{RESULTS}

\section{Extracts from adult rodent brain can nick duplex DNA specifically at $G \cdot T$ mispairs}

To study the ability of adult rodent brain to carry out DNA mismatch repair, we used synthetic oligonucleotides to generate duplex DNA molecules containing single-base mismatches. The test substrates used in these experiments (Neddermann and Jiricny, 1993) were duplex DNA molecules created by annealing synthetic 34-base oligonucleotides having the sequence shown in Figure 1. Different 34-mers were synthesized having different bases at the $\mathrm{N}$ position, so that by annealing different combinations of top and bottom oligos, perfectly matched duplexes or heteroduplexes containing different types of mismatches could be formed.

Extracts from the adult brain first were used to assay for specific nicking of heteroduplex DNA containing various mismatched bases (Fig. 1). As shown in Figurc 2, incubation of hetcroduplex DNA containing a $\mathrm{G} \cdot \mathrm{T}$ mismatch (labeled at the $5^{\prime}$ end of the T-containing strand) with brain extracts caused the production of a fragment that comigrates with the control AccI-cleaved DNA marker (lane 5). This cleaved fragment was not present when the same duplex was incubated in the absence of extract (lane 1). Comigration with the Accl-cleaved marker indicates that the duplex was nicked $5^{\prime}$ to the mismatched $\mathrm{T}$ (see also Fig. 4). When the same heteroduplex, labeled on the $5^{\prime}$ end of the $\mathrm{G}$ strand, was 
5' AATTCCCGGGGATCCGTCNACCTGCAGCCAAGCTT 3' 3.' TTAAGGGCCCCTAGGCAGNTGGACGTCGGTTCGAA5'

$$
\text { Hinc II }
$$

Figure 1. Oligonucleotides used to detect DNA mismatch nicking and repair in this study (after Neddermann and Jiricny, 1993). Experiments were performed using heteroduplex DNAs constructed by annealing the oligonucleotides shown above. Oligonucleotides were synthesized with either a $\mathrm{G}$ or an $\mathrm{A}$ in the $\mathrm{N}$ position of the top strand, and with a $\mathrm{C}, \mathrm{T}$, or $\mathrm{U}$ in the $\mathrm{N}$ position of the bottom strand. Annealing different pairs of $5^{\prime}$ end-labeled top- and bottom-strand oligos allowed the generation of perfectly matched duplexes or heteroduplexes containing the different types of mismatches used in this study.

incubated with extract, no nicking was detected (lane 2). Lack of nicking with the $\mathrm{G}$ strand-labeled duplex demonstrated that the nicking is specific to the strand containing the mismatched $\mathrm{T}$. Duplex DNA containing a G:C base pair was not nicked (lane 3); nor was a heteroduplex containing a $\mathrm{G} \cdot \mathrm{A}$ mismatch (lane 4), which is notable in that a $\mathrm{G} \cdot \mathrm{A}$ mismatch nicking activity has been reported in HeLa cells (Yeh et al., 1991).

Duplex DNA containing a $\mathrm{G} \cdot \mathrm{U}$ mismatch also was nicked, but to a larger extent than the $\mathrm{G} \cdot \mathrm{T}$ mismatch-containing duplex (lane 6). G.U mismatches are addressed by the enzyme uracil DNA glycosylase (Lindahl, 1993), which has been reported previously to be present in the brain (Weng and Sirover, 1993).

The results shown in Figure 2 suggest that the $\mathrm{G} \cdot \mathrm{U}$ mismatch nicking activity is higher than the $\mathrm{G} \cdot \mathrm{T}$ nicking activity in the same brain tissue extracts. To compare the relative amounts of the $\mathrm{G} \cdot \mathrm{T}$ and $\mathrm{G} \cdot \mathrm{U}$ nicking activities better, the experiment was repeated using a higher concentration of heteroduplex DNA. As shown in Figure 3 , again the $\mathrm{G} \cdot \mathrm{U}$ mismatch nicking activity is much more abundant than the $\mathrm{G} \cdot \mathrm{T}$ mismatch nicking activity in adult brain extracts.

In other experiments, we found that no nicking was observed using duplexes containing an $\mathrm{A} \cdot \mathrm{C}$ mismatch and that the $\mathrm{G} \cdot \mathrm{T}$ nicking activity was abolished by boiling the extracts before the assay (data not shown). Taken together, these data indicate that extracts from the adult rat brain have the capacity to specifically nick the T-containing strand of heteroduplex DNA containing a $\mathrm{G} \cdot \mathrm{T}$ mismatch.
Time course of $\mathbf{G} \cdot \mathbf{T}$ mismatch nicking in brain extracts

Wiebauer and Jiricny (1990) have shown that the first step in G.T mismatch repair in HeLa cells is carried out by thymine DNA glycosylase, which specifically removes the mismatched thymine residue from $\mathrm{G} \cdot \mathrm{T}$ mismatches, leaving an abasic site. The $\mathrm{T}$ strand-specific nicking of a $\mathrm{G} \cdot \mathrm{T}$-containing duplex shown above is consistent with the action of thymine DNA glycosylase. To address the possibility further that the $\mathrm{G} \cdot \mathrm{T}$ mismatch nicking activity in brain extracts is attributable to thymine glycosylase, we performed a time-course analysis. Purified thymine DNA glycosylase is notable for having very slow kinetics, acting with a time course on the order of hours (Neddermann and Jiricny, 1993). As shown in Figure 4 , the nicking at $\mathrm{G} \cdot \mathrm{T}$ mismatches progressed slowly; overnight incubation was necessary for significant cutting. This time course provides additional support for the hypothesis that thymine glycosylase is responsible for the G·T nicking activity.

\section{Nuclear extracts from adult brain neurons can repair $\mathbf{G} \cdot \mathbf{T}$ and $\mathbf{G} \cdot \mathbf{U}$ mismatches to $\mathbf{G}: \mathbf{C}$ base pairs}

The results described above indicate that brain extracts can nick heteroduplex DNA at sites of $\mathrm{G} \cdot \mathrm{T}$ mismatches. If the function of this activity in brain is to repair spontaneous or chemically induced deamination of $5-\mathrm{MeC}$ residues, then it remains to be demonstrated that $\mathrm{G} \cdot \mathrm{T}$ mismatches can be repaired to $\mathrm{G}: \mathrm{C}$ base pairs. To address this question, we isolated nuclei from the adult rat cerebellum and prepared nuclear extracts as described in Materials and Methods. Cerebellum was used because nuclei isolated by sucrose density ultracentrifugation from this tissue are predominately from granule cell neurons (Thompson, 1987), thus allowing the opportunity to study mismatch repair in nuclear extracts from adult neurons.

The repair assay (Wiebauer and Jiricny, 1989) takes advantage of the fact that the presence of a $\mathrm{G} \cdot \mathrm{T}$ mispair in the test heteroduplex DNA inactivates the SalI site in the T-containing strand (Fig. 1), preventing cleavage with this endonuclease. Repair of the $\mathrm{G} \cdot \mathrm{T}$ mismatch to a G:C base pair regenerates the SalI site, which can be monitored by treating the repaired DNA with SalI and detecting the appropriately sized Sall fragment in a polyacrylamide gel.

Heteroduplex DNA containing a $\mathrm{G} \cdot \mathrm{T}$ mismatch was incubated overnight with cerebellar nuclear extracts in the presence of all cofactors and nucleotides necessary for complete repair (see Materials and Methods). After incubation, the DNA was purified, digested with SalI, reprecipitated, and separated by gel electro-

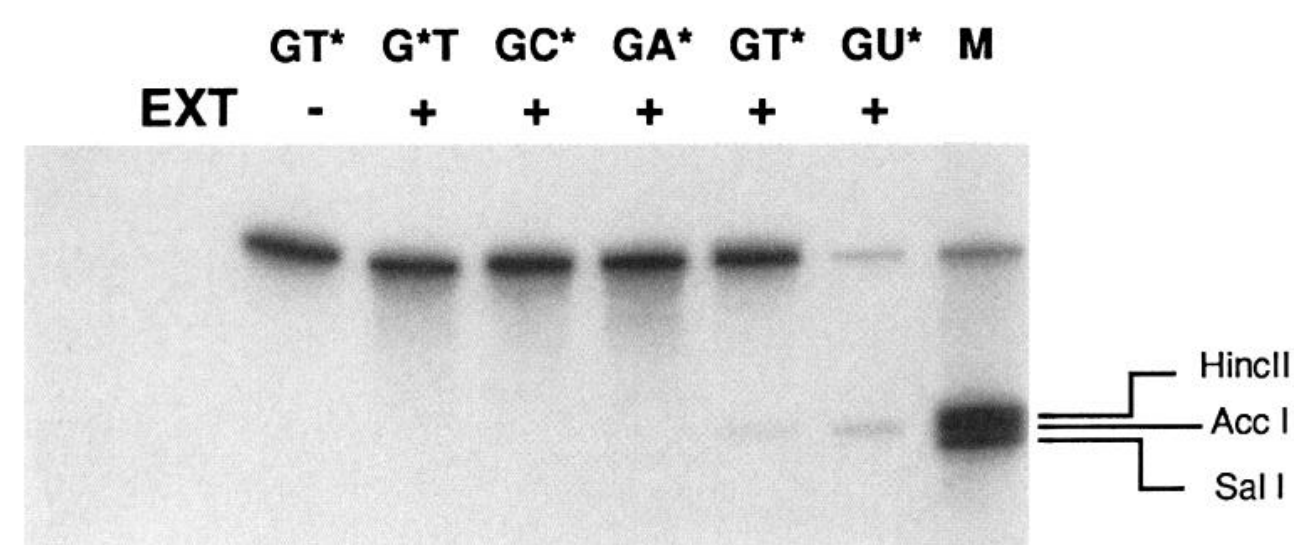

Figure 2. Nicking of mismatch containing heteroduplex DNA by adult rat brain extracts. Duplex DNAs containing the indicated bases at the $\mathrm{N}$ position of the test duplex (shown in Fig. 1) were incubated with brain extracts $(E X T)$ overnight. The EXT - lane received buffer instead of brain extract. The products were analyzed on an $18 \%$ denaturing gel. Asterisks indicate which strand was labeled. DNA markers were generated by end-labeling the C-containing strand of duplex DNA containing a $\mathrm{G}: \mathrm{C}$ base pair, then digesting with HincII, AccI, or SalI and mixing aliquots of each digest before loading on the gel. The product of the nicking reaction comigrates with the $A c c \mathrm{I}$ markers, indicating that it was cut $5^{\prime}$ to the mismatched $\mathrm{T}$ (see also Fig. 4). 

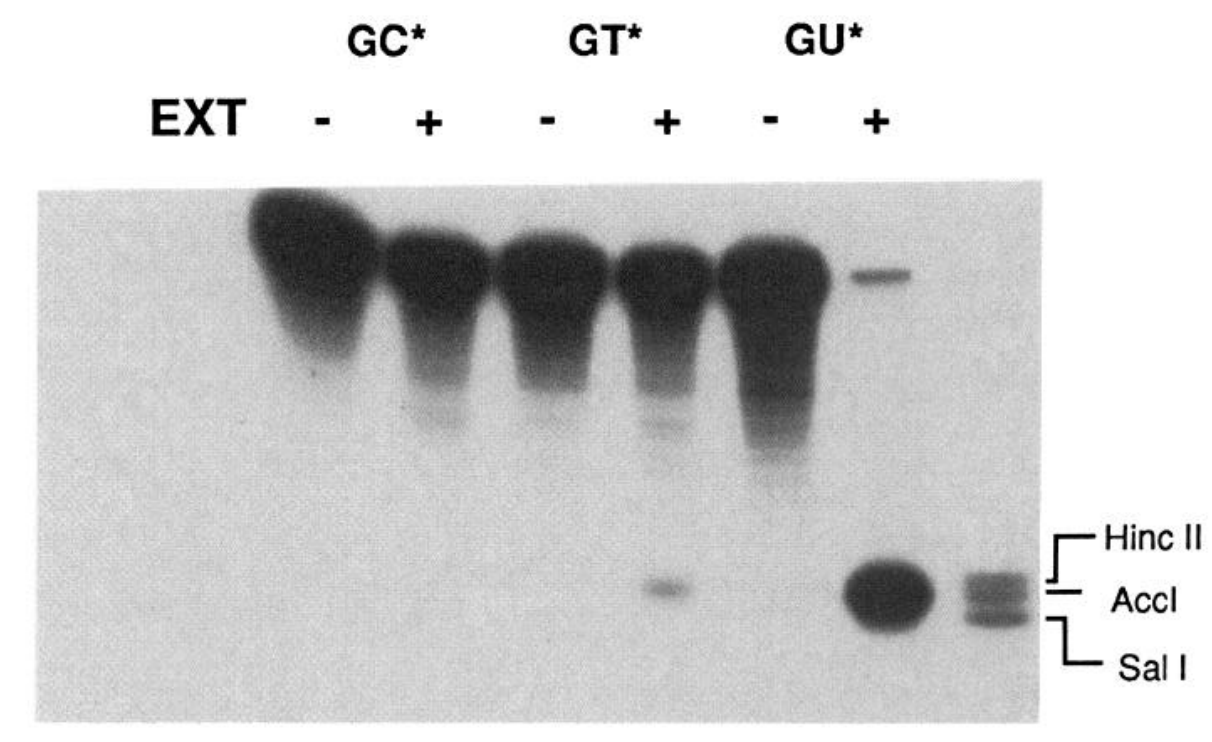

Figure 3. Comparison of $\mathrm{G} \cdot \mathrm{T}$ versus $\mathrm{G} \cdot \mathrm{U}$ nicking activities in brain cell extracts. Procedures were as described in Figure 2, except that higher concentrations of DNA substrate were used.

phoresis. Figure 5 shows the results of this experiment. Incubation of heteroduplex DNA containing a $\mathrm{G} \cdot \mathrm{T}$ mismatch with brain extracts causes a proportion of it to become digestible with SalI, as evidenced by the band comigrating with the SalI marker. This band was not present in the absence of SalI, indicating that it did not arise fortuitously during incubation. These data directly demonstrate that nuclear extracts from adult neurons can repair $\mathrm{G} \cdot \mathrm{T}$ mismatches to $\mathrm{G}: \mathrm{C}$ base pairs in vitro.

Cerebellar nuclear extracts also were capable of repairing $\mathrm{G} \cdot \mathrm{U}$ mismatches back to $\mathrm{G}: \mathrm{C}$ base pairs using the same assay (Fig. 6). The extent of repair of $\mathrm{G} \cdot \mathrm{U}$ mismatches is much greater than that of $\mathrm{G} \cdot \mathrm{T}$ mismatches, which parallels the relative differences in $\mathrm{G} \cdot \mathrm{T}$ versus $\mathrm{G} \cdot \mathrm{U}$ nicking activities (Fig. 3). Taken together, these data show that extracts from the adult brain nuclei can carry out DNA mismatch repair.

\section{Expression of DNA MTase activity in the brain}

Deamination of 5-MeC to $\mathrm{T}$ causes both a change in the DNA base sequence and a loss of methylation signal. Repair of the $G \cdot T$ mismatch to a $\mathrm{G}: \mathrm{C}$ base pair corrects the base sequence, but not the loss of methylation. For this purpose, DNA MTase also would need to be present. To address this possibility, we assayed MTase activity in extracts from different brain regions. As shown in Table 1, MTase activity was easily detectable in cell extracts prepared from all brain regions, and the highest levels were found in the cerebellum. For comparison, MTase activity in all brain regions was higher than in the liver, but lower than in the thymus, which is a highly proliferative tissue. Extracts from highly purified cerebellar nuclei had higher levels of MTase activity than did the whole-cell extracts (Table 1). This would be expected for a nuclear enzyme, and this result also directly demonstrates that MTase is present in neuronal nuclei, as is the $\mathrm{G} \cdot \mathrm{T}$ mismatch repair system.

Taken together, the data presented in this report indicate that the neurons from the adult brain have the capacity to repair $\mathrm{G} \cdot \mathrm{U}$ and $\mathrm{G} \cdot \mathrm{T}$ mismatches caused by the deamination of $\mathrm{C}$ and $5-\mathrm{MeC}$. Neurons also have DNA MTase activity, which would remethylate cytosine residues after $\mathrm{G} \cdot \mathrm{T}$ mismatch repair. These reactions are summarized in Figure 7.

\section{DISCUSSION}

Previous reports have demonstrated that the rodent brain contains several enzymes involved in DNA repair (see introductory remarks). Experiments showing the presence of individual repair enzymes indicate that the brain is capable of DNA repair in general, but they cannot show the specific types of repair processes of which the brain is capable. The present work demonstrates that complete DNA mismatch repair reactions can be performed in extracts from adult brain neurons, and provides the first direct demonstration that neurons from the adult mammalian brain are capable of carrying out two types of DNA mismatch repair - the repair of $\mathrm{G} \cdot \mathrm{T}$ and $\mathrm{G} \cdot \mathrm{U}$ mismatches.

In the present experiments, $\mathrm{G} \cdot \mathrm{T}$ and $\mathrm{G} \cdot \mathrm{U}$ mismatch repair was chosen for examination because these DNA mismatches are the only types that can occur naturally in nondividing cells such as neurons. $\mathrm{G} \cdot \mathrm{U}$ mismatches are caused by deamination of cytosine, and $\mathrm{G} \cdot \mathrm{T}$ mismatches are caused by the deamination of $5-\mathrm{MeC}$ (Lindahl, 1993; Wiebauer et al., 1993). Based on spontaneous mutation rates in vitro, and on the relative proportion of $\mathrm{C}$ and 5-MeC in mammalian DNA, it has been estimated that spontaneous cytosine deamination occurs $\sim 100-500$ times per human

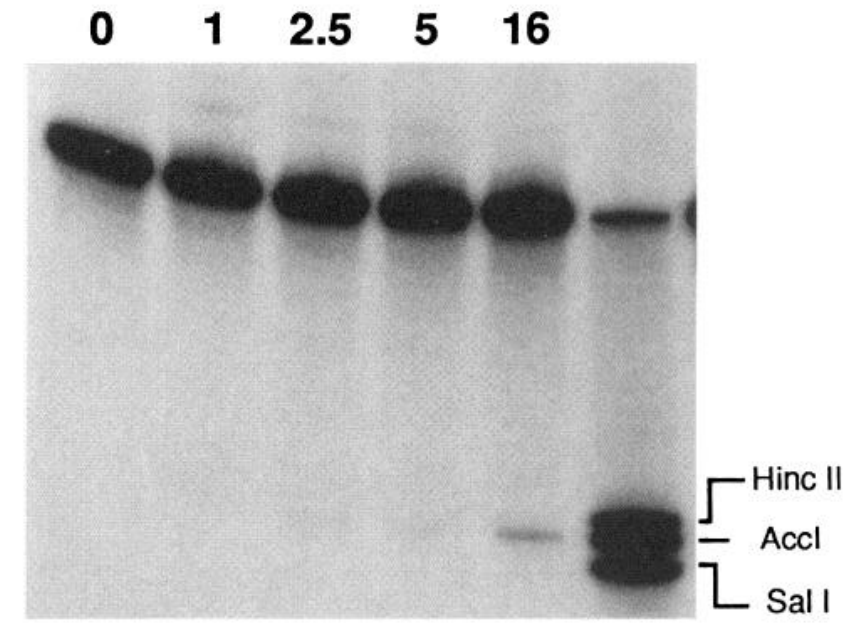

Figure 4. Time course of $\mathrm{G} \cdot \mathrm{T}$ nicking in brain extracts. A nicking assay was set up using the heteroduplex DNA containing a $\mathrm{G} \cdot \mathrm{T}$ mismatch (labeled on the T-containing strand), and aliquots were removed at the times indicated (in hr). The nicked fragment was detected by PAGE. Note the parallel migration of the nicked DNA with the $A c c$ I marker, indicating that the DNA was nicked $5^{\prime}$ to the mismatched T. 


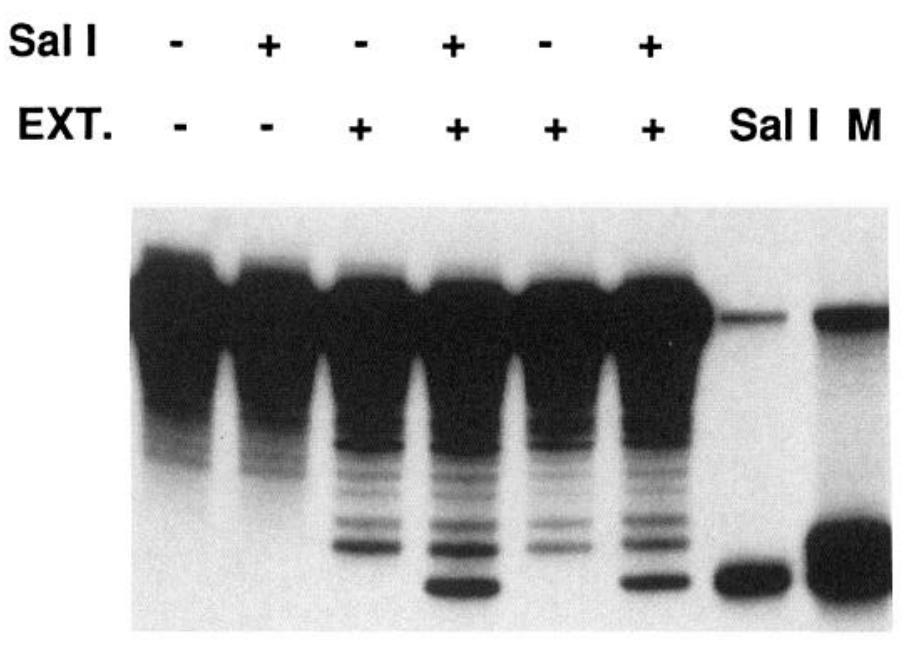

cell per day, and spontaneous deamination of 5-MeC occurs 1-20 times per human cell per day (Lindahl, 1993; Wiebauer et al., 1993; Shen et al., 1994). Thus, the much greater G·U repair activity versus $\mathrm{G} \cdot \mathrm{T}$ repair activity in brain cell extracts described in this paper is consistent with the view that these systems act to repair spontaneous deamination damage. In addition, the present results are also consistent with work showing that $\mathrm{G} \cdot \mathrm{T}$ mismatch repair is less efficient than $\mathrm{G} \cdot \mathrm{U}$ mismatch repair in cultured mammalian cells (Brown and Jiricny, 1987; Wiebauer et al., 1993).

In HeLa cell extracts, repair of $\mathrm{G} \cdot \mathrm{T}$ mismatches is initiated by the enzyme thymine DNA glycosylase (Wiebauer and Jiricny, 1990; Neddermann and Jiricny, 1993). Apparently identical G·T

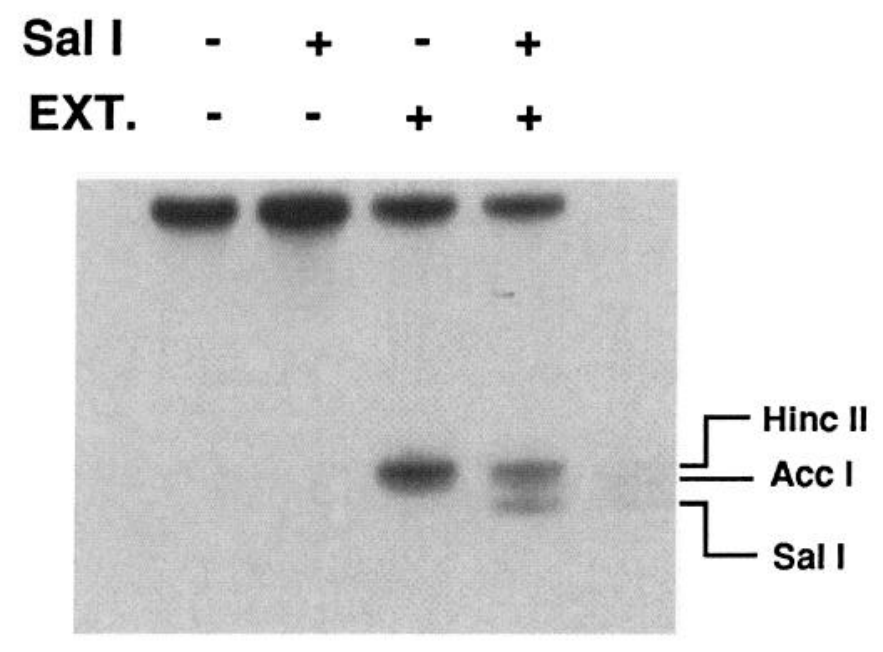

Figure 6. Repair of heteroduplex DNA containing a $\mathrm{G} \cdot \mathrm{U}$ mismatch. Exposure time, $2 \mathrm{~d}$. The lack of bands reflecting DNA degradation products in this figure compared with the G.T mismatch (Fig. 5) reflects that fact that the $G \cdot U$ repair system is more active in these extracts than the $\mathrm{G} \cdot \mathrm{T}$ repair system, allowing shorter exposure times.
Figure 5. Repair of heteroduplex DNA containing a G.T mismatch. Duplex DNA containing a $\mathrm{G} \cdot \mathrm{T}$ mismatch was incubated with $(+)$ or without $(-)$ neuronal nuclear extracts overnight and in the presence of deoxynucleotide triphosphates, $\mathrm{MgCl}_{2}$, and ATP (see Materials and Methods). Reaction products then were purified and treated with $2 \mathrm{U}$ of Sall $(+)$ or were left untreated $(-)$. Reaction products were purified again and separated by PAGE. Marker lanes: SalI, Duplex DNA containing a $\mathrm{G}: \mathrm{C}$ base pair that was digested with Sall; M, markers as described previously. The presence of a $\mathrm{G} \cdot \mathrm{T}$ mismatch blocks Sall digestion of the T-containing (labeled) strand (lane 2). Incubation of the $G \cdot T$ mismatchcontaining heteroduplex DNA with nuclear extract (lanes $3-6$ ) corrects the $\mathrm{G} \cdot \mathrm{T}$ mismatch to a $\mathrm{G}: \mathrm{C}$ base pair, which regenerates the SalI site. This is detected by the presence of a band comigrating with the SalI marker after SalI digestion of the repaired DNA. The band comigrating with the HincII marker likely reflects DNA molecules in which the G.T mismatch was repaired to a $\mathrm{G}: \mathrm{C}$, but which have not been ligated. Exposure time, 7 $\mathrm{d}$. The two right-most lanes show a shorter (2 d) exposure of the marker lanes for more detail.

mismatch nicking activities have been demonstrated in a number of other cultured cell lines (Griffin and Karran, 1993; SibghatUllah and Day, 1993). The present work is the first demonstration that $\mathrm{G} \cdot \mathrm{T}$ mismatch nicking activity is present in cells from the adult brain. The time-course and strand-specificity data presented in this paper, as well as the detection of immunoreactive thymine DNA glycosylase in adult brain nuclear extracts (P. Brooks and C. Marietta, unpublished data), are consistent with the hypothesis that thymine DNA glycosylase is responsible for removing $T$ residues from $\mathrm{G} \cdot \mathrm{T}$ mismatches in the adult rodent brain. Because the extent of $\mathrm{G} \cdot \mathrm{U}$ and $\mathrm{G} \cdot \mathrm{T}$ repair assayed in nuclear extracts is proportional to the relative amounts of $\mathrm{G} \cdot \mathrm{U}$ and $\mathrm{G} \cdot \mathrm{T}$ nicking activities, the limiting step in both types of mismatch repair likely is removal of the mismatched base. Also, because DNA polymerase $\beta$ is responsible for nucleotide incorporation during $\mathrm{G} \cdot \mathrm{T}$ (Wiebauer and Jiricny, 1990) and G.U (Dianov et al., 1992) repair in human cells, and because $\beta$ is the major DNA poly-

\begin{tabular}{|c|c|}
\hline Tissue & $\begin{array}{l}\text { Activity }(\mathrm{pmol} \cdot \mathrm{mg} \\
\left.\text { protein }^{-1} \cdot \mathrm{hr}^{-1} \pm \mathrm{SE}\right)\end{array}$ \\
\hline Liver & $0.28 \pm 0.01$ \\
\hline Thymus & $31.81 \pm 1.28$ \\
\hline Brainstem & $2.98 \pm 0.58$ \\
\hline Cortex & $3.07 \pm 0.57$ \\
\hline Striatum & $3.36 \pm 0.47$ \\
\hline Hippocampus & $3.63 \pm 0.74$ \\
\hline Cerebellum & $9.95 \pm 0.32$ \\
\hline Cerebellum nuclear extract & $31.38 \pm 0.72$ \\
\hline
\end{tabular}

DNA MTase activity in rat tissues and brain regions. Whole-cell extracts from different rat tissues and brain regions or from rat cerebellar nuclei were assayed for DNA MTase activity. Data presented are means $\pm \mathrm{SE}$ after subtracting background counts (see Materials and Methods). 

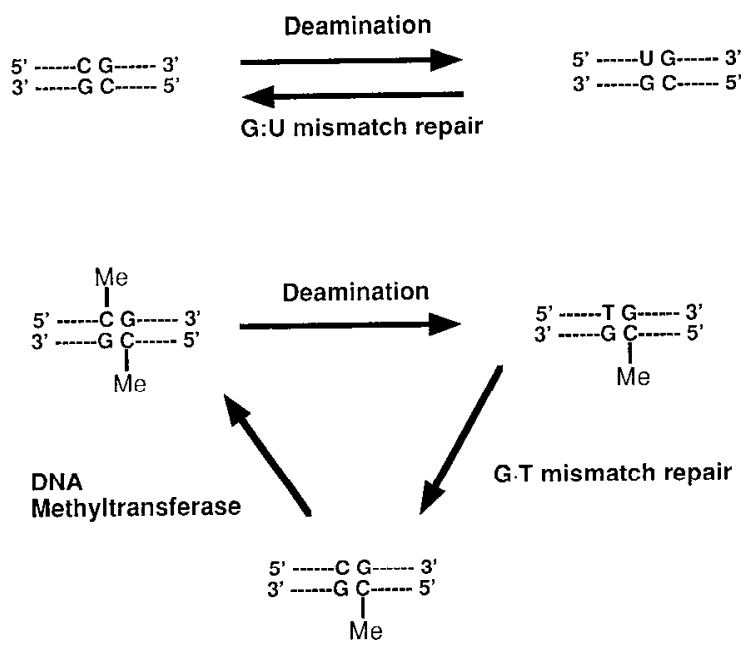

Figure 7. Summary of the mismatch repair reactions demonstrated in this paper for the repair of deamination damage in the adult brain. Top, Deamination of cytosine to uracil generates a $G \cdot U$ mispair, which is corrected back to a G:C base pair. Bottom, Deamination of 5-MeC gencrates a $G \cdot T$ mismatch, which is corrected to a $G: C$ pair by the $G \cdot T$ mismatch repair system. The newly incorporated cytosine then is methylated via the active hemimethylation function of mammalian DNA MTase (Bestor, 1993).

merase that is expressed in adult brain (Waser et al., 1979), it is likely that DNA polymerase $\beta$ is responsible for nucleotide incorporation during $\mathrm{G} \cdot \mathrm{T}$ and $\mathrm{G} \cdot \mathrm{U}$ repair in adult brain extracts.

In mammalian DNA, cytosine methylation is important for the regulation of gene expression and chromatin structure (Bird, 1992). The enzyme responsible for generating and maintaining DNA methylation patterns is DNA MTase (Bestor, 1993). Mice made deficient in DNA MTase by gene targeting do not survive beyond embryonic day 7 , indicating the crucial importance of DNA methylation for mammalian development (Li et al., 1992). Yen et al. (1992) and Goto et al. (1994) have demonstrated DNA MTase mRNA in the adult brain. The present work cxtends these results by showing that MTase enzyme activity is present in adult brain neurons and by proposing a functional role for this enzyme in the adult brain.

Methylation of specific cytosine residues is critical to the regulation of tissue-specific gene expression, to $\mathrm{X}$-chromosome inactivation, and to genomic imprinting (Bestor, 1993). Deamination of $5-\mathrm{MeC}$ to $\mathrm{T}$ could be doubly deleterious because it represents both a change in the primary sequence of DNA and a loss of the methylation signal, which potentially could result in the inappropriate expression of a silenced gene. The present results show that adult brain neurons contain both the $G \cdot T$ mismatch repair activity and DNA MTase. We propose that in vivo these systems act together to compensate for the biological effects of 5-MeC deamination. After deamination of a $5-\mathrm{MeC}$ residue in a symmetrically methylated $\mathrm{CpG}$ dinucleotide, the resulting $\mathrm{G} \cdot \mathrm{T}$ mismatch can be repaired to a $\mathrm{G}: \mathrm{C}$ base pair. This hemimethylated DNA molecule then can be methylated via the active maintenance methylation activity of DNA MTase (Fig. 7). Together, these reactions act to maintain DNA methylation patterns in neurons over time.

The strikingly higher level of MTase activity in brain versus liver (Table 1) is intriguing. This difference parallels differences in MTase RNA from different human (Yen et al., 1992) and rodent tissues (Jue et al., 1995) (P. Brooks, unpublished dala). DNA methylation has been considered to be associated closely with
DNA synthesis (Burdon and Adams, 1969; Turkington and Spielvogel, 1971); therefore, high levels of MTase were expected in thymus, a proliferative tissue. However, DNA synthesis is higher in the adult liver than in the adult brain (Weng and Sirover, 1993); thus, higher MTase activity in brain compared with liver does not parallel DNA synthesis in these tissues. $G \cdot T$ mismatch repair activity is roughly comparable in nuclei from adult brain and liver (P. Brooks, unpublished observations). Thus, the higher levels of DNA MTase in brain versus liver also do not parallel G.T mismatch repair activity. These observations suggest that, in addition to a role in the repair of $5-\mathrm{MeC}$ deamination damage described above, MTase in the brain has other functions as well.

In summary, we have shown that extracts from the adult brain can repair $\mathrm{G} \cdot \mathrm{T}$ and $\mathrm{G} \cdot \mathrm{U}$ mismatches. The ability to study complex DNA repair processes in brain extracts in vitro will be valuable in the analysis of other types of DNA repair in brain, such as the repair of oxidative DNA damage and in the study of DNA repair activity under experimental and pathological conditions.

\section{REFERENCES}

Bestor T (1993) Methylation patterns in the vertebrate genome. J NIH Res 5:57-60.

Bestor T, Coxon $\Lambda$ (1993) The pros and cons of DNA methylation. Curr Biol 3:384-386.

Bird A (1992) The essentials of DNA methylation. Cell 70:5-8.

Brown TC, Jiricny J (1987) A specific mismatclı repair event protects mammalian cells from loss of 5-methyl cytosine. Cell 50:945-50.

Burdon RH, Adams RP (1969) The in vivo methylation of DNA in mouse fibroblasts. Biochim Biophys Acta 174:322-329.

Cleaver JE (1968) Defective repair replication of DNA in Xeroderma pigmentosum. Nature 218:652-656.

Cleaver JE (1994) It was a very good year for DNA repair. Cell 76:1-4.

Dianov G, Price A, Lindahl T (1992) Generation of single-nucleotide repair patches following excision of uracil residues from. DNA Mol Cell Biol 12:1605-1612.

Evans DAP, van der Kleij AAM, Sonnemans MAF, Burbach JPH, van Lecuwen FW (1994) Frameshift mutations at two hot spots in vasopressin transcripts in post-mitotic neurons. Proc Natl Acad Sci USA 91:6059-6063.

Goto K, Numata M, Komura JI, Ono T, Bestor TH, Kondo H (1994) Expression of DNA methyltransferase gene in mature and immature neurons as well as proliferating cells in mice. Differentiation 56:39-44.

Griffin S, Karran P (1993) Incision at DNA G.T mispairs by extracts of mammalian cells occurs preferentially at cytosine methylation sites and is not targeted by a separate $G \cdot T$ binding reaction. Biochemistry 32:13032-13039.

Hanawalt P (1994) Transcription-coupled repair and human disease. Scicnce 266:1957-1958.

Jue K, Benoit G, Alcivar-Warren A, Trasler J (1995) Developmental and hormonal regulation of DNA methyltransferase in the rat testis. Biol Reprod 52:1364-1371.

Kuenzle CC (1985) Enzymology of DNA replication and repair in the brain. Brain Res Rev 10:231-245.

Li E, Bestor TH, Jaenisch R (1992) Targeted mutation of the DNA methyltransferase gene results in embryonic lethality. Cell 69:915-926.

Lindahl T (1993) Instability and decay of the primary structure of DNA. Nature 362:709-715.

Mazzarello P, Poloni M, Spadari S, Focher F (1992) DNA repair mechanisms in neurological disease: facts and hypotheses. J Neurol Sci 112:4-14.

Modrich P (1994) Mismatch repair, genetic stability, and cancer. Science 266:1959-1960.

Neddermann P, Jiricny J (1993) The purification of a mismatch-specific thymine-DNA glycosylase from HeLa cells. J Biol Chem 268: $21218-21224$.

Rao KS (1993) Genomic damage and its repair in the young and aging brain. Mol Neurobiol 7:23-48.

Rideout WM, Coetzee G, Olumi AF, Jones PA (1990) 5-Methyl cytosine as an endogenous mutagen in the human LDL receptor and $\mathrm{p} 53$ genes. Science 249:1288-1290. 
Robbins JH, Otsuka F, Tarone RE, Polinsky RJ, Brumback RA, Nee L (1985) Parkinson's disease and Alzheimer's disease: hypersensitivity to X-ray in cultured cell lines. J Neurol Neurosurg Psychiatry 48:916-948.

Sancar A (1994) Mechanisms of DNA excision repair. Science 266: $1954-1956$.

Scuderio D, Meyer SA, Clatterbuck BE, Tarone RE, Robbins JH (1981) Hypersensitivity to $N$-methyl- $N^{\prime}$-nitro- $N$-nitrosoguanidine in fibroblasts from patients with Huntington's disease, familial disautonia, and other primary neurodegenerations. Proc Natl Acad Sci USA 78:6451-6455.

Shen J-C, Rideout III JC, Jones PA (1994) The rate of hydrolytic deamination of 5-methyl cytosine in double-stranded DNA. Nucleic Acids Res 22:972-976.

Sibghat-Ullah J, Day RS (1993) DNA-substrate sequence specificity of human G.T mismatch repair activity. Nucleic Acids Res 21:1281-1287.

Tandan R, Robinson SH, Munzer JS, Bradley WG (1987) Deficient DNA repair in amyotrophic lateral sclerosis. J Neurol Sci 79:189-203.

Thompson RJ (1987) Isolation procedures and in vitro applications of cell nuclei from the mammalian brain. In: Neurochemistry: a practical approach (Turner AJ, Bachelard HS, eds), pp 225-242. London: IRL.

Troelstra C, Hesen W, Bootsma D, Hoeijmakers JH (1993) Structure and expression of the excision repair gene ERCC6, involved in the human disorder Cockayne's syndrome group B. Nucleic Acids Res 21:419-426.

Turkington RW, Spielvogel RL (1971) Methylation of deoxyribonucleic acid during hormonal stimulation of mammary cells in vitro. $\mathrm{J}$ Biol Chem 246:3835-3840.
Walker AP, Bachelard HS (1988) Studies on DNA damage and repair in the mammalian brain. J Neurochem 51:1394-1399.

Waser J, Hubscher U, Kuenzle CC, Spadari S (1979) DNA polymerase beta from brain neurons is a repair enzyme. Eur J Biochem 97:361-368.

Weng Y, Sirover MA (1993) Developmental regulation of the base excision repair enzyme uracil DNA glycosylase in the rat. Mutat Res 293:133-141.

Wiebauer K, Jiricny $\mathbf{J}(1989)$ In vitro correction of $\mathrm{G} \cdot \mathrm{T}$ mispairs to $\mathrm{G} \cdot \mathrm{C}$ pairs in nuclear extracts from human cells. Nature 339:234-236.

Wiebauer K, Jiricny J (1990) Mismatch-specific thymine DNA glycosylase and DNA polymerase beta mediate the correction of $\mathrm{G} \cdot \mathrm{T}$ mispairs in nuclear extracts from human cells. Proc Natl Acad Sci USA 87:5842-5845.

Wiebauer K, Neddermann P, Hughes M, Jiricny J (1993) The repair of 5-methyl cytosine deamination damage. In: DNA methylation: molecular biology and biological significance (Jost JP, Saluz HP, eds), pp 510-522. Basel: Birkhauser-Verlag.

Yeh Y-C, Chang D-Y, Masin J, Lu A-L (1991) Two nicking enzyme systems specific for mismatch-containing DNA in nuclear extracts from human cells. J Biol Chem 266:6480-6484.

Yen RWC, Vertino P, Nelkin B, Yu JJ, El Diery W, Cumaraswamy A, Lennon GG, Trask B, Celano P, Baylin SB (1992) Isolation and characterization of the human DNA methyltransferase cDNA. Nucleic Acids Res 20:2287-2291. 